ENTREPRENEURSHIP AND SUSTAINABILITY ISSUES

ISSN 2345-0282 (online) http://jssidoi.org/jesi/

2020 Volume 8 Number 2 (December)

http://doi.org/10.9770/jesi.2020.8.2(83)

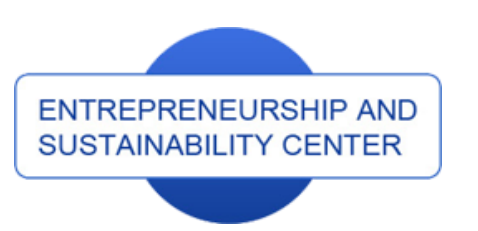

Publisher

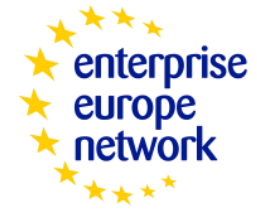

Business Support on Your Doorstep

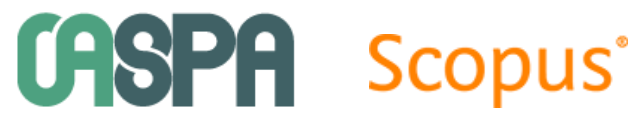

http://jssidoi.org/esc/home

1) Clarivate

Analytics

\title{
ENVIRONMENTAL ISSUES AND SOCIAL RESPONSIBILITY: A SCIENTOMERIC ANALYSIS USING CITESPACE ${ }^{*}$
}

\author{
Zixuan Zeng ${ }^{1 *}$, Thammanoon Hengsadeekul ${ }^{2}$ \\ 1,2 Faculty of Logistics and Digital Supply Chain, Naresuan University, 99 Moo.9, Thapo, Mueang, 65000, Phitsanulok, \\ Thailand \\ ${ }^{1}$ Guangxi University of Finance and Economics, No. 100, Mingxiuxi Road, Xixiangtang District, 530000, Nanning, China
}

E-mails: ${ }^{1 *}$ zixuanz61@nu.ac.th (Corresponding author); ${ }^{2}$ thammanoonh@nu.ac.th

Received 15 September 2020; accepted 15 November 2020; published 30 December 2020

\begin{abstract}
Environmental issues and social responsibility have a significant impact on the natural ecological system and economic development. Hence, it is essential to find a relative balance path between them. Previous studies have sought to explore environmental and social responsibility rather than seek solutions from a systematic perspective, and there seems to be a lack of a systematic quantitative review of periodic solutions or details. To identify multiple impacts and relationships between environmental issues and social responsibility and to illustrate emerging trends and challenges, this article proposes a scientometrics review based on 1,336 articles published from 2001 to 2020, through co-occurrence analysis and co-citation analysis together with cluster and burstiness analysis to reveal the depth and breadth of emerging research. This research demonstrates the research paradigm of environmental issues and social responsibility, extending from a single stakeholder level to a systematic strategic perspective of multiple organizations and stakeholders. The results provide researchers and practitioners with a deeper understanding of future directions and implications.
\end{abstract}

Keywords: environmental issues; social responsibility; strategy; scientometrics; review

Reference to this paper should be made as follows: Zeng, Z., Hengsadeekul, T. 2020. Environmental Issues and Social Responsibility: A Scientomeric Analysis Using Citespace. Entrepreneurship and Sustainability Issues, 8(2), 1419-1436. http://doi.org/10.9770/jesi.2020.8.2(83)

JEL Classifications: Q01, Q56, O35

\footnotetext{
* The research was supported by the National Natural Science Foundation of China (No. 11761012) and the National Social Science Fund of China (No. 16AGL017).
} 


\section{ENTREPRENEURSHIP AND SUSTAINABILITY ISSUES}

ISSN 2345-0282 (online) http://jssidoi.org/jesi/

2020 Volume 8 Number 2 (December)

http://doi.org/10.9770/jesi.2020.8.2(83)

Make your research more visible, join the Twitter account of ENTREPRENEURSHIP AND SUSTAINABILITY ISSUES: @Entrepr69728810

\section{Introduction}

Many scholars and experts have been concerned about environmental issues for a long time and considered a strategy by many corporates (Reinhardt, 1998; Aragón-Correa et al., 2008; Tvaronavičienè \& Ślusarczyk, 2019; Ji et al., 2019; Cismas et al., 2019; Khan et al., 2020; Yeganeh Kia, 2020; Mazzoni, 2020).

Meanwhile, the discussion on social responsibility has never stopped in academic circles. After one of the representative scholar Archie B. Carroll (1979) proposed a three-dimensional model and conducted the evolution of social responsibility (Archie B. Carroll, 1999), numerous scholars were exploring the relationship between social responsibility and other variables, especially from the corporate aspect. These include the strategic implication of social responsibility (McWilliams et al., 2006), social responsibility and financial performance (Cochran \& Wood, 1984; McGuire et al., 1988), and Islamic religious education (Husni, 2020). In the mid of 2010s, Zeng et al. (2015) determined megaproject social responsibility (MSR) as the social responsibility of major infrastructure projects involving the policies and practices of the stakeholders who participated through the whole project life-cycle that reflects the responsibilities for the well-being of the wider society. An intelligent concept combined with the development trends, people's needs, social responsibility, and environmental issues.

One of the most controversial issues on infrastructure is building megaprojects. It cost many social resources and environmental resources, and they are never just a scaled-down version of small projects (Flyvbjerg, 2014). With the advent of megaprojects, a series of social and environmental problems began to emerge. Megaprojects can bring huge benefits like pulling effect on the economy, regional influence, employment, and disaster protection. However, it has some drawbacks, like environmental problems and socio-economic issues (He et al., 2019). Therefore, environmental compensation is as vital as technology, economics, culture, and supervision, and it has received significant attention from many stakeholders (Cowell, 1997). The earliest and most popular way of environmental compensation could be the compensation principle in Germany's 1970s (Peters, 1993). The essential environmental compensation connotes that the beneficiary of ecosystem service provides a conditional payment system to the environmental income service provider to achieve environmental protection through incentive or reward.

In general, environmental degradation regulations have been introduced to solve those serious problems, but the activities are still lacking in consistency and improvement. Therefore, environmental issues need to be investigated profoundly, and innovation must be required. This paper aims to illustrate the transformation of environmental issues from a corporate level to a strategic level through antecedence studies using Scientometric analysis. It will shed light on studies on the strategic field and provide managers or policymakers with a decision. To further explore the aspects involved in the research on the environmental field and social responsibility, the specific objectives of this paper are as follows; (1) To identify the development of environmental issues and social responsibility, and publish journals and articles from 2001 to 2020 using the subject category co-occurrence network. (2) To determine the holistic research state-of-art in environmental issue and social responsibility through co-occurring keywords analysis and document co-citation analysis, as well as a burstiness analysis to illustrate the abrupt changes and emerging trends of the development in the research area.

\section{Literature review}

There have been few studies that systematically investigated the relationship between environmental problems and social responsibility. Hence, we presented articles on environmental issues and social responsibility to discover critical findings and research trends in environmental issues and social responsibility research. 


\section{ENTREPRENEURSHIP AND SUSTAINABILITY ISSUES}

ISSN 2345-0282 (online) http://jssidoi.org/jesi/

2020 Volume 8 Number 2 (December)

http://doi.org/10.9770/jesi.2020.8.2(83)

Make your research more visible, join the Twitter account of ENTREPRENEURSHIP AND SUSTAINABILITY ISSUES: @Entrepr69728810

Fernández et al. (2003) reviewed the organizational culture and human resources in environmental management. From the perspective of management duty and organizational culture to establish internal stakeholders' recognition, organizational participation in environmental issues, environmental training, environmental motivation, and organizational innovation to illustrate the significance of enterprises' environmental strategy. Reinhardt \& Stavins (2010) demonstrated the relationship between corporate social responsibility (CSR), business strategy, and environment. Corporates who are willing to participate in CSR, including more extensive companies, lousy performance on environmental issues, more pressure from the NGOs and the public, and final product production. CSR activities from private firms like the transparency of CSR report, CSR plans, environmental management systems, or plans related to social beneficially. For business strategy and environment, Margolis et al. (2007) suggested that profitable companies are more willing to participate in CSR activities, and in the long run, environmental protection would bring better profits to companies (Reinhardt \& Stavins, 2010). Scholars intend to identify more empirical relationships in the so-called multidisciplinary. Based on a large number of studies, more in-depth studies on environment, social responsibility, and business are emerging. In a recent study, J. Liu et al. (2020) examined the relationship between ISO 14001, trade openness, and environmental pressure. The results showed no correlations between them, but the relationship varies from region to region in developing countries. An environmental management system (EMS) is a crucial factor in gaining competitiveness in the market. Bravi et al. (2020) examined how the enterprise with an EMS based on ISO 14001:2015 perceives the change caused by the revision of standards. Using a questionnaire survey in 284 Italian companies, the benefits of those corporates include risk prevention, better management of environmental activities, and a new goal to reduce energy and waste. Kolk (2016) demonstrated the social responsibility issues in international business. Over the past 50 years, three themes were commonly discussing including the green environment, ethic, rights, and responsibilities, poverty, and sustainable development. Ye et al. (2020) reviewed the studies on CSR's contribution to sustainable development, which is an excellent beginning to invest the balance between environment and sustainable development.

\section{Research Methodology}

Web of Science (WoS) was selected as the database of Scientometric data for research sampling. Its consistency with the core collection: Science Citation Index Expanded (SCI-EXPANDED), Social Sciences Citation Index (SSCI), Arts \& Humanities Citation Index (A\&HCI), and Emerging Sources Citation Index (ESCI), both sources are positively influencing and significant in academia (W. Liu et al., 2020; Zhu \& Liu, 2020). Firstly, a preanalysis was conducted with the retrieval code: $T S=$ (environmental management $*$ AND social responsibility) and refined by peer-reviewed reviews and articles to found out the synonym terms. The research rule at the end TS $=$ (environmental compensation OR environmental offset OR compensatory mitigation OR restoration OR environmental remediation OR environmental management) AND (social responsibility OR CSR) AND (strategy OR strategical). We retrieved a total of 1,336 papers. Figure 1 indicates the details of the bibliography presented from 2001 to 2020 . 
ENTREPRENEURSHIP AND SUSTAINABILITY ISSUES

ISSN 2345-0282 (online) http://jssidoi.org/jesi/

2020 Volume 8 Number 2 (December)

http://doi.org/10.9770/jesi.2020.8.2(83)

Make your research more visible, join the Twitter account of ENTREPRENEURSHIP AND SUSTAINABILITY ISSUES: @Entrepr69728810

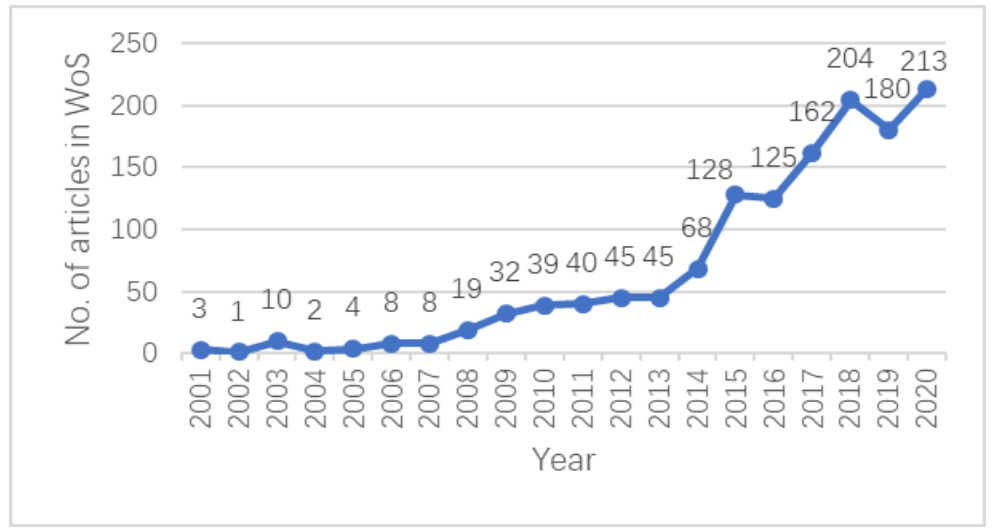

Figure 1. The number of papers published from 2001 to 2020

Source: processed primary data

This Scientometric analysis includes author co-citation analysis, document co-citation analysis, and co-word analysis. (Chaomei, 2017). It is based on mathematical static and computing techniques (Wang et al., 2018). It is essential to understand that transient articles change the perspective and development of the scientific field. Internal and external causes are included when the style of a specific research field suddenly changed, and the field trends emerge (C. Chen, 2006). We researched the abstract, title, and keywords for selected papers from WoS and put them into Citespace software to determine theme groups. Citespace is a tool that demonstrates an excellent bibliographic visualization used to analyze the kinds of literature. It can also uniquely represent research frontiers and knowledge bases, the evolution of research frontiers, and the literature that plays a key role in the evolution process (Y. Chen et al., 2015; Fang et al., 2018; Zhao et al., 2019).

This study employs co-occurrence and co-citation analysis, specifically on the subject category of co-occurrence analysis, keyword co-occurrence analysis, document co-citation analysis, and supplementary with cluster analysis and burstiness analysis. Since the keywords of scientific literature are the basic units that reflect the knowledge component of a specific subject domain, the relationship and structure of research hotspots in the field can be indirectly mapped co-occurrence frequency, which is a significant indicator (Hsin-Ning \& Pei-Chun, 2010). Cocitation analysis refers to a group of literature cited by one article or the same group of literature at the same time, the cited literature constitute the co-citation relationship, and the analysis of them is called co-citation analysis (Özmen Uysal, 2010), the cited frequency is the most comment index and draws co-cited network. Within the cocited network, the greater the literature's centrality at key nodes, the more classic literature with significant theoretical innovation, and hot literature leading the scientific research frontier. The research frontiers and knowledge bases of environmental management and social responsibility are described as visual network forms, and their contents and structures are deeply analyzed through the above methods.

\section{Results and discussion}

\subsection{Co-word analysis}

In this section, several research themes from the WoS database on environmental issues and social responsibility have been illustrated and analyze through the co-word analysis method. Specifically, subject category cooccurrence network and keyword co-occurrence network. 
ENTREPRENEURSHIP AND SUSTAINABILITY ISSUES

ISSN 2345-0282 (online) http://jssidoi.org/jesi/

2020 Volume 8 Number 2 (December)

http://doi.org/10.9770/jesi.2020.8.2(83)

Make your research more visible, join the Twitter account of ENTREPRENEURSHIP AND SUSTAINABILITY ISSUES: @Entrepr69728810

\subsubsection{Subject category co-occurrence network}

The subject category co-occurrence network is shown in Figure 2 below. It consisted of 57 nodes and 104 connecting lines representing the research subjects of environmental issues and social responsibilities, including 57 classes, and the character was a multidisciplinary study. The size of nodes representing the number of papers in this subject and the fuchsia color of the node's outer ring represents that subject's centrality. Figure 3 illustrates the most frequent top 20 subjects in this area, including business and economics, environmental science and ecology, management, environmental studies and sciences, science and technology, green and sustainable, engineering, social science, and the like. These represent environmental and social responsibility research, starting to extend the research field on environmental and ecology issues. It is important to pay more attention to the balance between the environment and economic development. However, the highest centrality discipline is the bridge between them: engineering and environmental (125), with the centrality of 1.29.

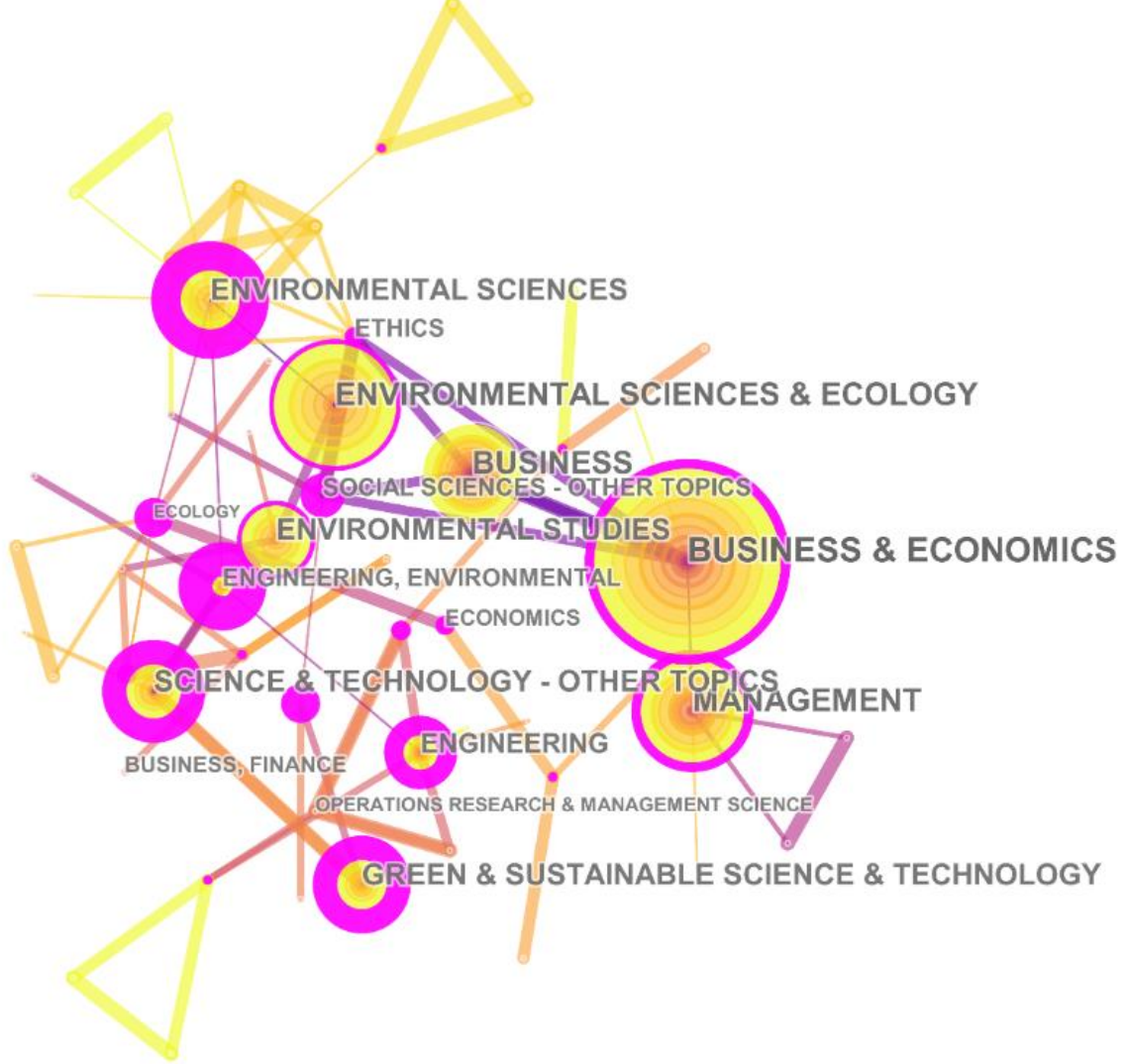

Figure 2. Subject category co-occurrence network Source: processed primary data 
ENTREPRENEURSHIP AND SUSTAINABILITY ISSUES

ISSN 2345-0282 (online) http://jssidoi.org/jesi/

2020 Volume 8 Number 2 (December)

http://doi.org/10.9770/jesi.2020.8.2(83)

Make your research more visible, join the Twitter account of ENTREPRENEURSHIP AND SUSTAINABILITY ISSUES: @Entrepr69728810

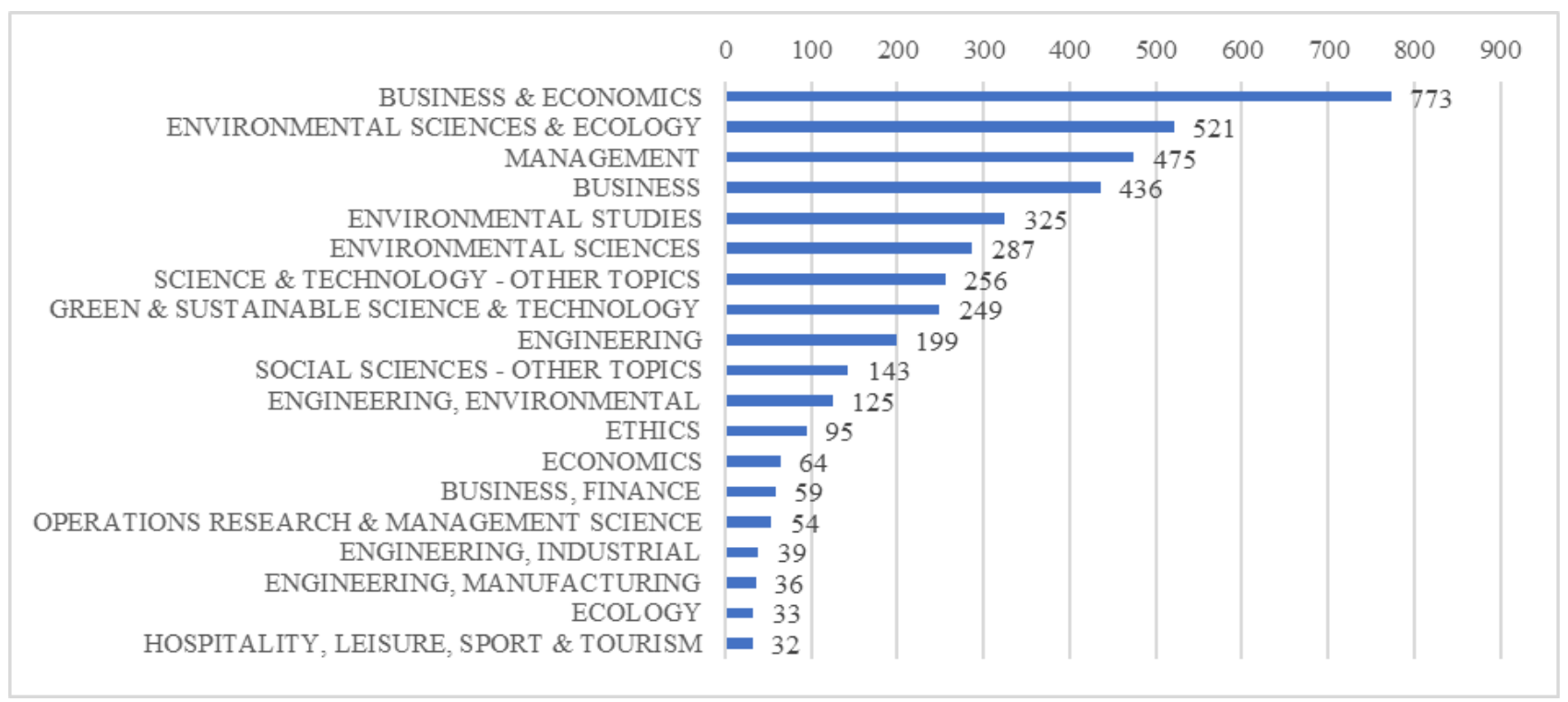

Figure 3. Top 20 research areas of environmental issues and social responsibility

Source: processed primary data

\subsubsection{Keyword co-occurrence network and burstiness}

Figure 4 shows the keyword co-occurrence network of this research field and it consists of 199 nodes and 1638 links. The size of the node is proportional to the frequency of keyword occurrence. The top 15 keywords with frequency were corporate social responsibility (frequency $=643$ ), strategy (frequency $=457$ ), management (frequency $=401$ ), performance (frequency $=315$ ), sustainability (frequency $=311$ ), social responsibility (frequency $=211)$, financial performance $($ frequency $=203)$, impact (frequency $=188)$, csr $($ frequency $=174)$, environmental management (frequency $=160)$, green (frequency $=156)$, resource based view (frequency $=121)$, perspective (frequency $=119$ ), firm (frequency $=116$ ), and supply chain management (frequency $=113$ ), respectively. It is important to mention that corporate social responsibility and CSR is the same in which many scholars are studying on it, social responsibility ranked sixth since the responsibility should not be only from corporates perspective. The burstiness demonstrates the most significant research area and the number of citations increased rapidly over a short period of time (Zhao et al., 2019). Totally 30 keywords with the strongest citation bursts were detected. The top five most strengthen keywords are stakeholder management (burst strength $=6.36$, 2010-2014), issue (burst strength $=6.21,2009-2012$ ), perspective (burst strength $=5.74,2017-2018$ ), ethics (burst strength $=4.99,2009-2015$ ), and economic performance (burst strength $=4.79,2013-2015$ ), with the period of its emergence. From 2017 to 2020, environmental disclosure (burst strength $=3.13$ ), CSR (burst strength $=4.31$ ), stakeholder engagement (burst strength $=3.81$ ), institutional theory (burst strength $=3.30$ ), and reputation (burst strength $=3.06$ ) illustrate that during these period scholars were paying more attention on them. 
ENTREPRENEURSHIP AND SUSTAINABILITY ISSUES

ISSN 2345-0282 (online) http://jssidoi.org/jesi/

2020 Volume 8 Number 2 (December)

http://doi.org/10.9770/jesi.2020.8.2(83)

Make your research more visible, join the Twitter account of ENTREPRENEURSHIP AND SUSTAINABILITY ISSUES: @Entrepr69728810

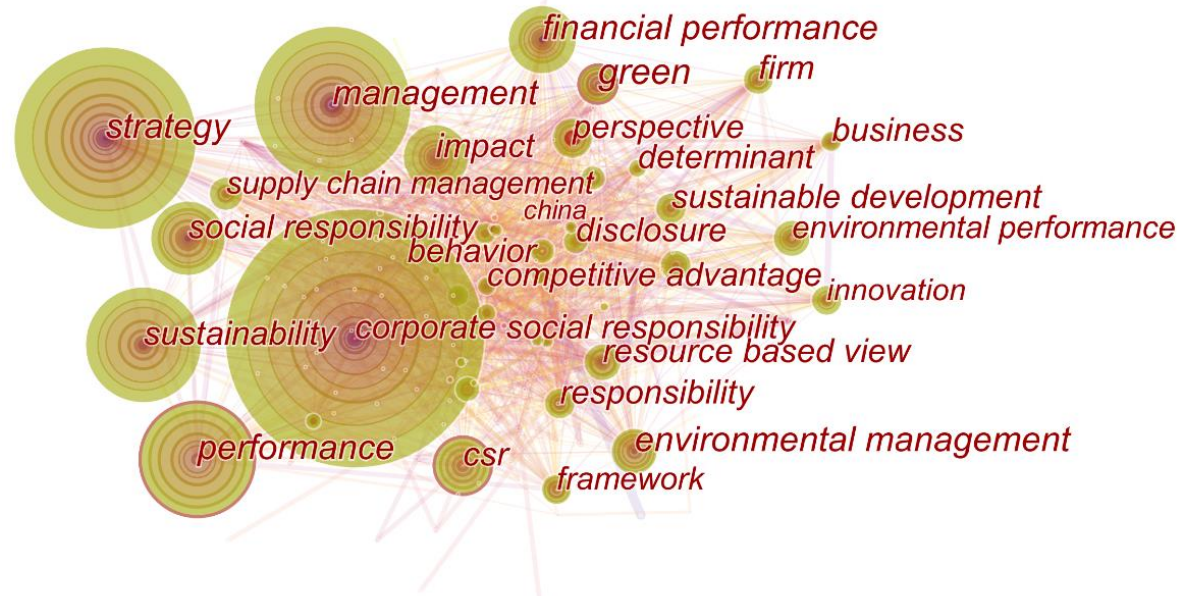

Figure 4. Keyword co-occurrence network Source: processed primary data

\subsection{Co-citation analysis}

Co-citation analysis is defined as the frequency with which two articles are cited simultaneously in another article (Edge, 1979; Small, 1973; Vanraan, 1990). In this section, the document, author, and journal co-citation network will be applied together with the clustering analysis. According to 1,336 records from the processed primary data from 2001 to 2020, accurate visualization of each network is shown in the corresponding section.

\subsubsection{Document co-citation network}

Figure 5 shows the landscape view of the document co-citation network and clusters. It consisted of 341 nodes and 432 links between 2001 and 2020. The labels of a cluster are presented depending on the cluster size. The weighting algorithm is following the log-likelihood ratio (LLR) to ensure the precision of clustering. It is essential to mention that the modularity $\mathrm{Q}$ is equal to 0.7607 (Q > 0.3), which is relatively high. It means that these clusters are justified by being divided into loosely coupled clusters (He et al., 2017), since there are a lot of small clusters as a result of the mean silhouette, which is a relatively low value equal to 0.5098 ( $\mathrm{ms}>0.7$ ) (Wang et al., 2018). The module's color represents the corresponding average year of the study co-citation of each cluster, and the label color corresponds to the module color. The indicator of the color map is illustrated in Figure 6. 


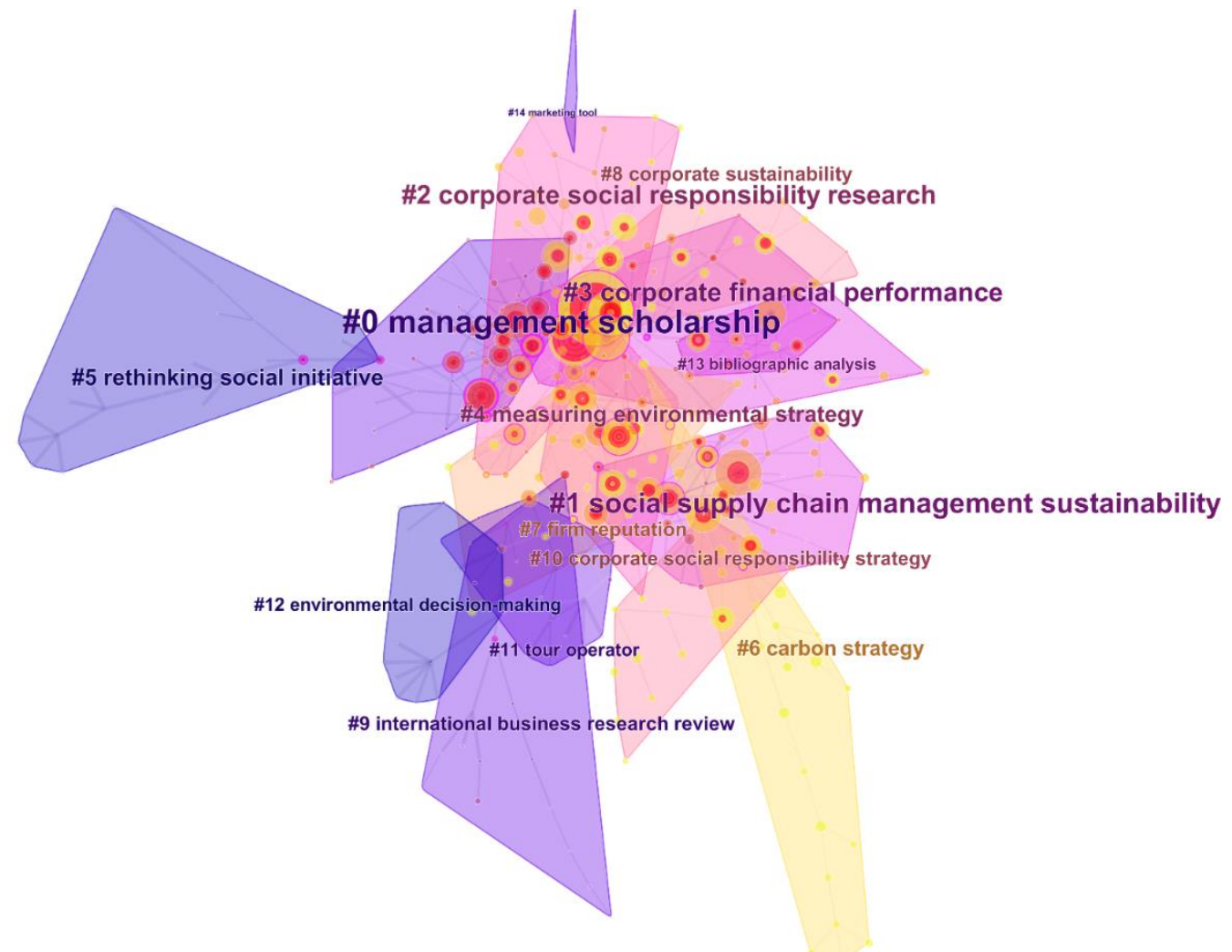

Figure 5. Document co-citation network and clusters Source: processed primary data

Figure 6. The indicator of the color map Source: processed primary data

There are a total of 14 clusters in this study, and the size of clusters depends on the number of papers. For instance, in Table 1, cluster\#0 is the largest cluster, with the silhouette value of 0.791, which is lower than a smaller cluster, yet it is also considered as a high degree of homogeneity (Chaomei, 2017). The mean year represents the average publish year for a cluster, which illustrates whether the cluster contains older or more recent documents. For cluster \#1, \#2, \#3, and \#4, the mean year is around 2010, the mean year of cluster \#0 and \#5 is 2004 and 1998, respectively. More importantly, cluster \#6 with the mean year in 2015 and a high silhouette value of 0.934 means the high consistency of studies, and the representative papers are essential for the cluster, and the most frequent co-citation is the representative literature. 


\section{ENTREPRENEURSHIP AND SUSTAINABILITY ISSUES}

ISSN 2345-0282 (online) http://jssidoi.org/jesi/ 2020 Volume 8 Number 2 (December)

http://doi.org/10.9770/jesi.2020.8.2(83)

Make your research more visible, join the Twitter account of ENTREPRENEURSHIP AND SUSTAINABILITY ISSUES: @Entrepr69728810

Table 1. Top 7 co-citation clusters of environmental issues and social responsibility

\begin{tabular}{|c|c|c|c|c|c|}
\hline Cluster ID & Size & $\begin{array}{c}\text { Silhouet } \\
\text { te }\end{array}$ & $\begin{array}{c}\text { Mean } \\
\text { (Year) }\end{array}$ & Custer Label & Representative Literature \\
\hline$\# 0$ & 45 & 0.791 & 2004 & management scholarship & Porter and Kramer (2006) \\
\hline$\# 1$ & 35 & 0.827 & 2008 & $\begin{array}{c}\text { social supply chain } \\
\text { management sustainability }\end{array}$ & Seuring and Müller (2008) \\
\hline$\# 2$ & 31 & 0.856 & 2010 & CSR research & Surroca et al. (2010) \\
\hline$\# 3$ & 30 & 0.72 & 2008 & corporate financial performance & Orlitzky et al. (2011) \\
\hline$\# 4$ & 23 & 0.774 & 2009 & $\begin{array}{c}\text { measuring environmental } \\
\text { strategy }\end{array}$ & Hillman and Keim (2001) \\
\hline$\# 5$ & 23 & 0.989 & 1998 & rethinking social initiative & Shaukat et al. (2016) \\
\hline$\# 6$ & 20 & 0.934 & 2015 & carbon strategy & \\
\hline
\end{tabular}

Source: processed primary data

Cluster \#0 'management scholarship' consists of 45 papers. Porter and Kramer (2006) proposed a new perspective on the relationship between business and society using a zero-sum game to analyze corporate success and social welfare. Bansal (2005) illustrated that corporates' sustainable development has a relationship between resourcebased and institutional factors. The media pressure is important in the early stage, even though opportunities from the resources still existed over time, but this may depend on the corporate characteristics. Orlitzky et al. (2003) illustrated the relationship between corporate social/environmental performance and corporate financial performance and shows that performed social responsibility and little extend of environmental responsibility could increase more performance.

Cluster \#1 'social supply chain management sustainability' Seuring \& Müller (2008) reviewed papers on the topic of sustainable supply chain management from 1994 to 2007 and came up with two strategies on risk and performance of supplier management and sustainable project supply chain management. Moreover, the authors found out that little researches from the perspective of social aspects and sustainable development. Carter Craig and Rogers Dale (2008) introduced sustainable development into supply chain management, extended the concept of sustainability, and further strengthened this research field. Vachon and Klassen (2008) illustrated the environmental collaboration between upstream suppliers and downstream customers. The results have shown that processing performance will come closer with upstream suppliers, whereas product-based performance is more on the cooperation with downstream customers (Husaini et al., 2020).

Cluster \#2 and \#3, 'CSR research' and 'corporate financial performance,' Cheng et al. (2014) illustrated the CSR strategy would cause better access to finance. The result has shown that stakeholder participation and transparency of CSR were a benefit for corporate capital constraints, and further examined relationships driven from the social and environmental dimensions. Surroca et al. (2010) demonstrated no direct relationship between corporate responsibility and financial performance but formed an indirect relationship with a mediator of intangible resources, Rudyanto \& Pirzada (2020). Carroll \& Shabana (2010) presented CSR's business cases and how the corporate gained benefit from policies, activities, and practices. Orlitzky et al. (2011) illustrated the importance of strategic CSR and environmental sustainability, and Gimenez et al. (2012) examined the relationship between environmental programmers and social practices and the triple bottom line (environmental, social, and economic performance).

Cluster \#5 'rethinking social initiative' Hillman \& Keim (2001) demonstrated the shareholder value, stakeholder management, and social problem participation, and revealed that establishment of a better relationship with 


\section{ENTREPRENEURSHIP AND SUSTAINABILITY ISSUES}

ISSN 2345-0282 (online) http://jssidoi.org/jesi/

2020 Volume 8 Number 2 (December)

http://doi.org/10.9770/jesi.2020.8.2(83)

Make your research more visible, join the Twitter account of ENTREPRENEURSHIP AND SUSTAINABILITY ISSUES: @Entrepr69728810

stakeholders would assist corporates to explore intangible and tangible assets, and McWilliams \& Siegel (2000) demonstrated the relationship between CSR to the financial performance from positive, negative, and neutral aspects, and the results showed that the relationship was neutral.

Cluster \#4 and \#6 'measure environmental strategy' and 'carbon strategy. Aguinis \& Glavas (2012) reviewed 588 articles and 102 books with a comprehensive CSR analysis from the potential mechanism micro-based view. Darnall et al. (2010) proposed a sized moderated stakeholder model to contribute to stakeholder theory. The result showed that small-sized corporations were more sensitive to the value chain, internal regulation, and stakeholder pressures. It also illustrated the stakeholder pressure, and environmental strategies were modified according to the company size. Aguinis and Glavas (2012) illustrated that the more intention of social responsibility from the board, the more environmental and social performance are. Besides, this phenomenon was endogenous and selfreinforcing, which means that the difference between leaders increased, and it was also called competitive advantage. Liao et al. (2015) proposed suggestions on improving corporate governance and climate change strategies from the board and environmental committees. Helfaya \& Moussa (2017) illustrated the relationship between the broad CSR strategy and the quantity and quality of environmental sustainability disclosure from the evidence of the UK. The result showed that it was critical of the broad CSR strategy for the stakeholder's legitimacy and accountability.

The top 20 papers with the highest citation, first author's name, and publication year are shown in Table 2. After reviewing these top 20 citation articles, the research fields included the review of corporate social responsibility (CSR) (No. 1, 12), the competitive advantage of nations and CSR (No. 2, 6), CSR works and affects the financial performance (No. 4, 5, 18, 19), the resource-based view of corporate (No. 11), stakeholder and environmental strategy (No. 7, 10), corporate sustainability (No. 13, 14, 15), sustainable supply chain management and social responsibility (No. 3, 9, 20), and the relationship between either stakeholder, financial performance, and environmental issues (No. 7, 8, 16, 17).

Table 2. Top 20 articles with highest citation on environmental issues and social responsibility

\begin{tabular}{|c|c|c|c|c|c|}
\hline No. & Cite & Articles & No. & Cite & Articles \\
\hline 1 & 78 & Aguinis and Glavas (2012) & 11 & 33 & Hart (1995) \\
\hline 2 & 54 & Porter (2011) & 12 & 33 & Archie B Carroll and Shabana (2010) \\
\hline 3 & 50 & Seuring and Müller (2008) & 13 & 33 & Bansal (2005) \\
\hline 4 & 48 & Cheng et al. (2014) & 14 & 29 & Eccles et al. (2014) \\
\hline 5 & 48 & Surroca et al. (2010) & 15 & 28 & Stefan and Paul (2008) \\
\hline 6 & 40 & Porter and Kramer (2006) & 16 & 28 & Dixon-Fowler et al. (2013) \\
\hline 7 & 39 & Darnall et al. (2010) & 17 & 28 & Vachon and Klassen (2008) \\
\hline 8 & 34 & Aragón-Correa et al. (2008) & 18 & 28 & Matten and Moon (2008) \\
\hline 9 & 34 & Carter Craig and Rogers Dale (2008) & 19 & 27 & Flammer (2012, 2013) \\
\hline 10 & 34 & Sarkis et al. (2010) & 20 & 25 & Carter Craig and Liane Easton (2011) \\
\hline
\end{tabular}

Source: processed primary data

In addition, 144 burstiness articles were detected. The top seven articles are Porter \& Kramer (2006) with a strength of 13.94, from 2010 to 2014, Bansal (2005) with a strength of 13.91, from 2007 to 2013, Orlitzky et al. 
ENTREPRENEURSHIP AND SUSTAINABILITY ISSUES

ISSN 2345-0282 (online) http://jssidoi.org/jesi/

2020 Volume 8 Number 2 (December)

http://doi.org/10.9770/jesi.2020.8.2(83)

Make your research more visible, join the Twitter account of ENTREPRENEURSHIP AND SUSTAINABILITY ISSUES: @Entrepr69728810

(2003) with strength 12.45, from 2007 to 2011, Seuring \& Müller (2008) with strength 12.34, from 2012 to 2016, Sharma \& Henriques (2005) with strength 11.52, from 2007 to 2012, Buysse \& Verbeke (2003) with strength 11.40, from 2007 to 2011, Carroll \& Shabana (2010) with strength 11.01, from 2016 to 2018.

Social responsibility and strategic CSR and environmental strategy are hot research fields since it is covered by cluster \#0, \#1, \#4, \#6. Hence, four research topics could be identified: sustainable supply chain management with social responsibility (cluster \#0, \#1), environmental carbon strategy (cluster \#4, \#6), CSR with stakeholder engagement and corporate financial performance (cluster \#2, \#3, \#5).

\subsubsection{Author co-citation network}

This section illustrates the number of times the author was cited. As shown in Figure7, this network consists of 254 nodes and 413 links, reflecting the indirect partnership formed by common references. Therefore, the top five citation authors are: Michael E. Porter ( $\mathrm{f}=432$, UK), Stuart L Hart ( $\mathrm{f}=342$, USA), Pratima (Tima) Bansal ( $\mathrm{f}=$ 302, Canada), Sanjay Sharma ( $\mathrm{f}=282$, USA), and Abagail McWilliams ( $\mathrm{f}=243$, USA). Those authors' nationalities illustrated that articles on social responsibility and environmental issues areas had received widespread attention in the US, the UK, and Canada.

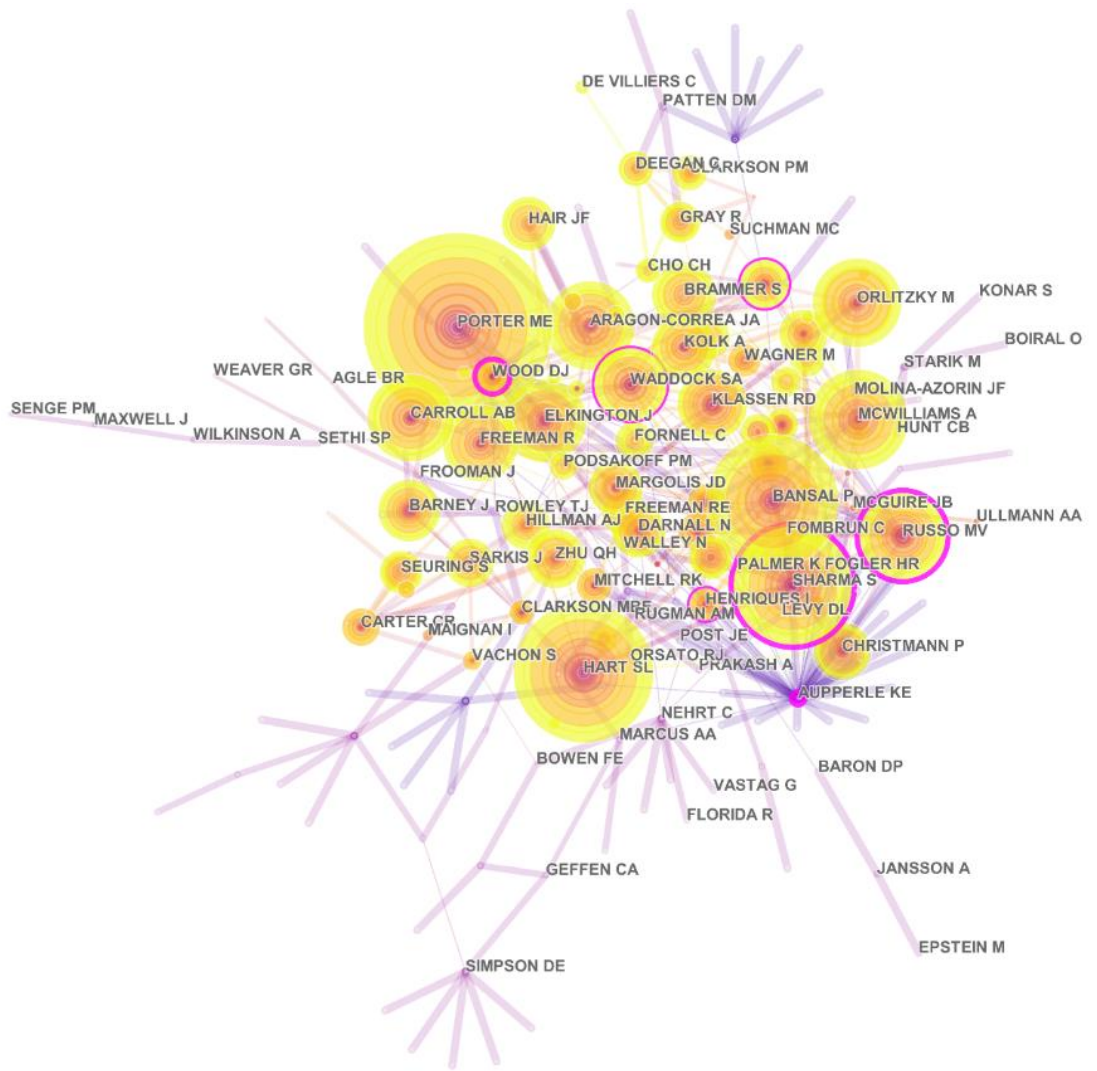

Figure 7. Author co-citation network Source: processed primary data 
ENTREPRENEURSHIP AND SUSTAINABILITY ISSUES

ISSN 2345-0282 (online) http://jssidoi.org/jesi/

2020 Volume 8 Number 2 (December)

http://doi.org/10.9770/jesi.2020.8.2(83)

Make your research more visible, join the Twitter account of ENTREPRENEURSHIP AND SUSTAINABILITY ISSUES: @Entrepr69728810

\subsubsection{Journal co-citation network}

There are 184 various journals in Figure 8, revealing that research on social responsibility and environmental issues covers various fields. The nodes' large size means more co-citation frequency, and nodes with purple color edges represent the journal's centrality. A journal with high centrality shows the importance of that journal, and articles from that journal cover a wider span. Table 3 shows the top 10 co-citation journals and the percentage of co-citation frequency among total co-citation frequency. Additionally, we found 55 burst journals. Those articles from these journals have received a large amount of attention in a short period. The top five are: Journal of Environmental Economics and Management (burst = 24.36, 2003 to 2015), Social Responsibility Journal (burst = 20.42, 2018 to 2020, UK), British Journal of Management (burst = 20.33, 2013 to 2017), Accounting, Auditing \& Accountability Journal (burst $=17.81,2016$ to 2020), and Journal of Economic Perspectives (burst $=17.41,2008$ to 2014).

Table 3. Top 10 journals with highest co-citation frequency

\begin{tabular}{|c|c|c|c|}
\hline No. & $\begin{array}{c}\text { Co-citation } \\
\text { frequency }\end{array}$ & Journal Name & Percent (\%) \\
\hline 1 & 951 & J BUS ETHICS & $5.5 \%$ \\
\hline 2 & 801 & ACAD MANAGE REV & $4.7 \%$ \\
\hline 3 & 708 & STRATEGIC MANAGE J & $4.1 \%$ \\
\hline 4 & 707 & J CLEAN PROD & $4.1 \%$ \\
\hline 5 & 694 & ACAD MANAGE J & $4.0 \%$ \\
\hline 6 & 539 & BUS STRATEG ENVIRON & $3.1 \%$ \\
\hline 7 & 506 & HARVARD BUS REV & $2.9 \%$ \\
\hline 8 & 503 & BUSINESS STRATEGY EN & $2.9 \%$ \\
\hline 9 & 484 & J MANAGE & $2.8 \%$ \\
\hline 10 & 458 & J MANAGE STUD & $2.7 \%$ \\
\hline
\end{tabular}


ENTREPRENEURSHIP AND SUSTAINABILITY ISSUES

ISSN 2345-0282 (online) http://jssidoi.org/jesi/

2020 Volume 8 Number 2 (December)

http://doi.org/10.9770/jesi.2020.8.2(83)

Make your research more visible, join the Twitter account of ENTREPRENEURSHIP AND SUSTAINABILITY ISSUES: @Entrepr69728810

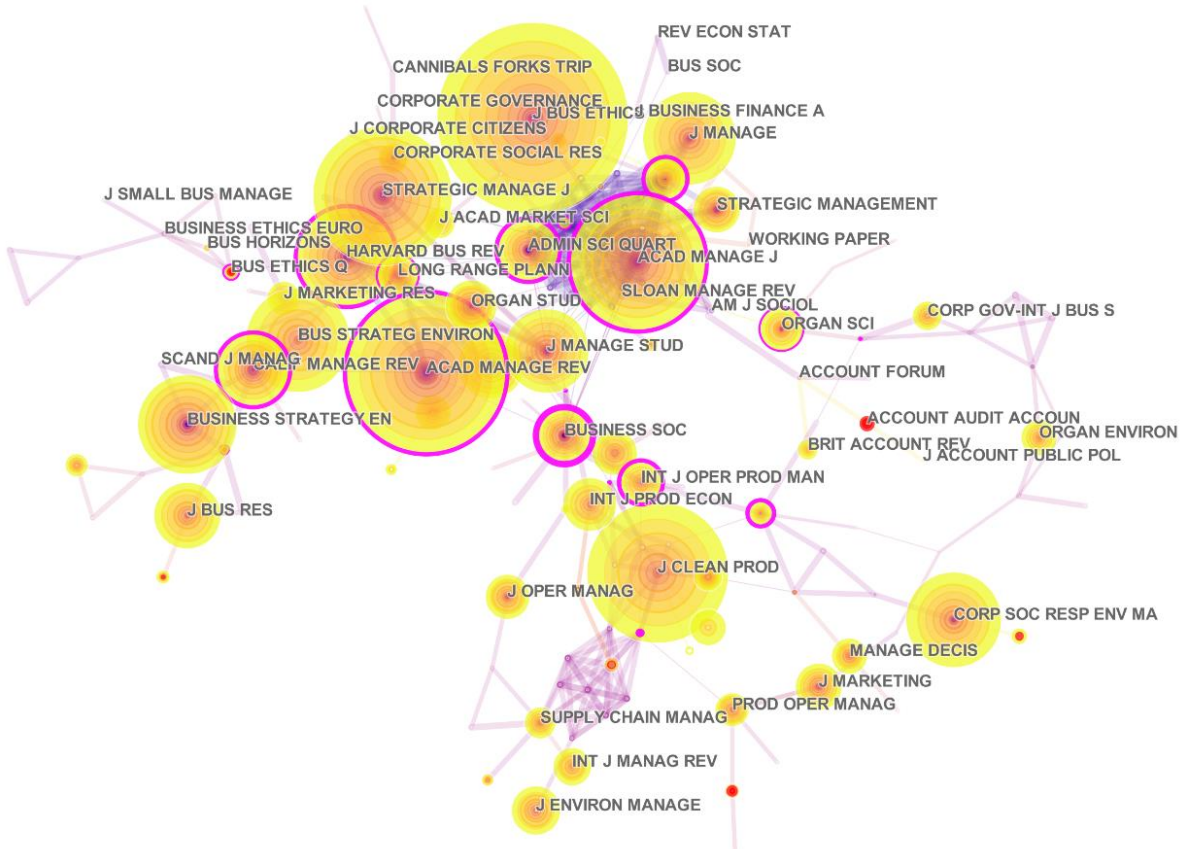

Figure 8. Journal co-citation network Source: processed primary data

\section{Conclusions}

Based on 1,336 records related to environmental issues and social responsibility through subject category cooccurrence analysis, keyword co-occurrence, author, journal, and document co-citation analysis, this study analyzed the current situation and development trend of this field. The emergence of environmental issues has brought a series of research problems and substantive problems to experts, scholars, and even entrepreneurs. With the development of the economy and the increasingly severe environmental issues, maintaining a relatively balanced growth in this ecosystem has become a hot topic. According to the finding from this research, we articulate that the research field of environmental issues and social responsibility maintain a hot topic and is continually emerging. Meanwhile, research related to social responsibility has been catching significant attention from academia and empirical practice.

Firstly, several research subjects related to business \& economics, environmental sciences \& ecology, management, business, environmental studies, and science \& technology acquired the most documentation. Secondly, through the keyword co-occurrence network and burstiness analysis, and through the analysis of cooccurrence and emergence of keywords, this research has found a shift in the research paradigm in this field, from focusing on a single level of environmental issues to emphasizing broad organizational strategies, and from an individual or even government-centric perspective to a wide range of organizations and stakeholders and even the entire ecological perspective. Besides, we found that a sustainable supply chain may assist in this balancing act, but much research is needed. 


\section{ENTREPRENEURSHIP AND SUSTAINABILITY ISSUES}

ISSN 2345-0282 (online) http://jssidoi.org/jesi/

2020 Volume 8 Number 2 (December)

http://doi.org/10.9770/jesi.2020.8.2(83)

Make your research more visible, join the Twitter account of ENTREPRENEURSHIP AND SUSTAINABILITY ISSUES: @Entrepr69728810

Although we have the advantages of the assorted procedure described above, our research still has several challenges. Firstly, using the Web of Science database might lead to some missing points in the analysis. Scopus is another reliable database that is advised to use another database when improving this type of research in the future. Secondly, even though the 1,336 papers identified by co-occurrence analysis used Scientometric method to classify topics, the topic coverage of the identified papers may depend mainly on the authors' subjective judgment.

In future studies, there are three directions that we recommended. Firstly, the guide refers to stakeholder participation in environmental issues from a systematic viewpoint. Secondly, the direction on establishing a social-responsibility-based framework and embedded in supply chain management and sustainability. Thirdly, the direction of environmental strategy, from the meso view, is significant for corporates to estimating and planning the strategy under a particular context. The context could be either a country or a specific area. In addition, the most important and essential rule is legitimacy, followed by other social responsibility aspects to support local development and environmentally friendly equilibration. From the macro perspective, the system's improvement on social and environmental/ecology will promote economic development sustainability since the environment is not the only barrier of development. Therefore, institutional differences and mechanism gaps under diverse social circumstances and environmental contexts are worth exploring.

\section{References}

Aguinis, H., \& Glavas, A. (2012). What We Know and Don't Know About Corporate Social Responsibility: A Review and Research Agenda. Journal of management, 38(4), 932-968. https://doi.org/10.1177/0149206311436079

Aragón-Correa, J. A., Hurtado-Torres, N., Sharma, S., \& García-Morales, V. J. (2008). Environmental strategy and performance in small firms: A resource-based perspective. Journal of environmental management, 86(1), 88-103. https://doi.org/https://doi.org/10.1016/j.jenvman.2006.11.022

Bansal, P. (2005). Evolving sustainably: A longitudinal study of corporate sustainable development. Strategic management journal, 26(3), 197-218. https://doi.org/10.1002/smj.441

Bravi, L., Santos, G., Pagano, A., \& Murmura, F. (2020). Environmental management system according to ISO 14001:2015 as a driver to sustainable development. Corporate Social Responsibility and Environmental Management, n/a(n/a). https://doi.org/10.1002/csr.1985

Buysse, K., \& Verbeke, A. (2003). Proactive environmental strategies: A stakeholder management perspective. Strategic management journal, 24(5), 453-470. https://doi.org/10.1002/smj.299

Carroll, A. B. (1979). A Three-Dimensional Conceptual Model of Corporate Performance. Academy of management review, 4(4), 497-505. https://doi.org/10.5465/amr.1979.4498296

Carroll, A. B. (1999). Corporate Social Responsibility: Evolution of a Definitional Construct. Business \& society, 38(3), 268-295. https://doi.org/10.1177/000765039903800303

Carroll, A. B., \& Shabana, K. M. (2010). The business case for corporate social responsibility: A review of concepts, research and practice. International journal of management reviews, 12(1), 85-105. https://doi.org/10.1111/j.1468-2370.2009.00275.X

Carter Craig, R., \& Liane Easton, P. (2011). Sustainable supply chain management: evolution and future directions. International journal of physical distribution \& logistics management, 41(1), 46-62. https://doi.org/10.1108/09600031111101420

Carter Craig, R., \& Rogers Dale, S. (2008). A framework of sustainable supply chain management: moving toward new theory. International journal of physical distribution \& logistics management, 38(5), 360-387. https://doi.org/10.1108/09600030810882816 


\section{ENTREPRENEURSHIP AND SUSTAINABILITY ISSUES}

ISSN 2345-0282 (online) http://jssidoi.org/jesi/

2020 Volume 8 Number 2 (December)

http://doi.org/10.9770/jesi.2020.8.2(83)

Make your research more visible, join the Twitter account of ENTREPRENEURSHIP AND SUSTAINABILITY ISSUES: @Entrepr69728810

Chaomei, C. (2017). Science Mapping: A Systematic Review of the Literature. Journal of Data and Information Science, 2(2), 1-40. https://doi.org/https://doi.org/10.1515/jdis-2017-0006

Chen, C. (2006). CiteSpace II: Detecting and visualizing emerging trends and transient patterns in scientific literature. Journal of the American Society for information Science and Technology, 57(3), 359-377. https://doi.org/10.1002/asi.20317

Chen, Y., Chen, C., Luan, C., hu, Z., \& Wang, X. (2015). CiteSpace 知识图谱的方法论功能 (The methodology function of CiteSpace mapping knowledge domains). 科学学研究 (Studies in Science of Science), 33, 242-253. https://doi.org/10.16192/j.cnki.1003$\underline{2053.2015 .02 .009}$

Cheng, B., Ioannou, I., \& Serafeim, G. (2014). Corporate social responsibility and access to finance. Strategic management journal, 35(1), 1-23. https://doi.org/10.1002/smj.2131

Cismas, L.M., Miculescu, A., Negrut, L., Negrut, V., Otil, M.D. \& Vadasan, I. (2019). Social Capital, Social Responsibility, Economic Behavior and Sustainable Economic Development - An Analysis of Romania's Situation. Transformations in Business \& Economics, 18, No 2A (47A), pp.605-627.

Cochran, P. L., \& Wood, R. A. (1984). Corporate Social Responsibility and Financial Performance. Academy of management Journal, 27(1), 42-56. https://doi.org/10.5465/255956

Cowell, R. (1997). Stretching the Limits: Environmental Compensation, Habitat Creation and Sustainable Development. Transactions of the Institute of British Geographers, 22(3), 292-306. https://doi.org/10.1111/j.0020-2754.1997.00292.x

Darnall, N., Henriques, I., \& Sadorsky, P. (2010). Adopting Proactive Environmental Strategy: The Influence of Stakeholders and Firm Size. Journal of management studies, 47(6), 1072-1094. https://doi.org/10.1111/j.1467-6486.2009.00873.x

Dixon-Fowler, H. R., Slater, D. J., Johnson, J. L., Ellstrand, A. E., \& Romi, A. M. (2013). Beyond “does it pay to be green?" A metaanalysis of moderators of the CEP-CFP relationship. Journal of Business ethics, 112(2), 353-366. https://doi.org/10.1007/s10551-012$\underline{1268-8}$

Eccles, R. G., Ioannou, I., \& Serafeim, G. (2014). The Impact of Corporate Sustainability on Organizational Processes and Performance. Management Science, 60(11), 2835-2857. https://doi.org/10.1287/mnsc.2014.1984

Edge, D. (1979). Quantitative Measures of Communication in Science: A Critical Review. History of science, 17(2), 102-134. https://doi.org/10.1177/007327537901700202

Fang, Y., Yin, J., \& Wu, B. (2018). Climate change and tourism: a scientometric analysis using CiteSpace. Journal of Sustainable Tourism, 26(1), 108-126. https://doi.org/10.1080/09669582.2017.1329310

Fernández, E., Junquera, B., \& Ordiz, M. (2003). Organizational culture and human resources in the environmental issue: a review of the literature. The International Journal of Human Resource Management, 14(4), 634-656. https://doi.org/10.1080/0958519032000057628

Flammer, C. (2012). Corporate Social Responsibility and Shareholder Reaction: The Environmental Awareness of Investors. Academy of management Journal, 56(3), 758-781. https://doi.org/10.5465/amj.2011.0744

Flyvbjerg, B. (2014). What you Should Know about Megaprojects and Why: An Overview. Project Management Journal, 45(2), 6-19. https://doi.org/10.1002/pmj.21409

Gimenez, C., Sierra, V., \& Rodon, J. (2012). Sustainable operations: Their impact on the triple bottom line. International journal of production economics, 140(1), 149-159. https://doi.org/https://doi.org/10.1016/j.ijpe.2012.01.035

Hart, S. L. (1995). A Natural-Resource-Based View of the Firm. Academy of management review, 20(4), 986-1014. https://doi.org/10.5465/amr.1995.9512280033

He, Q., et al. (2019). Managing social responsibility for sustainability in megaprojects: An innovation transitions perspective on success. Journal of Cleaner Production, 241, 118395. https://doi.org/https://doi.org/10.1016/j.jclepro.2019.118395 


\section{ENTREPRENEURSHIP AND SUSTAINABILITY ISSUES}

ISSN 2345-0282 (online) http://jssidoi.org/jesi/

2020 Volume 8 Number 2 (December)

http://doi.org/10.9770/jesi.2020.8.2(83)

Make your research more visible, join the Twitter account of ENTREPRENEURSHIP AND SUSTAINABILITY ISSUES: @Entrepr69728810

He, Q., Wang, G., Luo, L., Shi, Q., Xie, J., \& Meng, X. (2017). Mapping the managerial areas of Building Information Modeling (BIM) using scientometric analysis. International Journal of Project Management, 35(4), 670-685. https://doi.org/https://doi.org/10.1016/j.ijproman.2016.08.001

Helfaya, A., \& Moussa, T. (2017). Do Board's Corporate Social Responsibility Strategy and Orientation Influence Environmental Sustainability Disclosure? UK Evidence. Business Strategy and the Environment, 26(8), 1061-1077. https://doi.org/10.1002/bse.1960

Hillman, A. J., \& Keim, G. D. (2001). Shareholder value, stakeholder management, and social issues: what's the bottom line? Strategic management journal, 22(2), 125-139. https://doi.org/10.1002/1097-0266(200101)22:2<125::AID-SMJ150>3.0.CO;2-H

Hsin-Ning, S., \& Pei-Chun, L. (2010). Mapping knowledge structure by keyword co-occurrence: a first look at journal papers in Technology Foresight. Scientometrics, 85(1), 65-79. https://doi.org/10.1007/s11192-010-0259-8

Husni, H. (2020). The effectiveness of the social responsibility program for Islamic religious education through the participatory action research method. The Social Studies: An International Journal, 6(1), 103-116. Retrieved from http://fsshjournal.org/index.php/scr/article/view/107

Husaini; Pirzada, K., Saiful, 2020. Risk Management, Sustainable Governance Impact on Corporate Performance. Journal of Security and Sustainability Issues, 9(3), 993-1004. https://doi.org/10.9770/jssi.2020.9.3(23)

Ji, Z., Li, P. \& Zheng, X. (2019). Manufacturing Agglomeration and Environmental Efficiency in China: Insights from the Panel Threshold Model. Transformations In Business \& Economics, 18, No 1 (46), 257-277.

Khan, S., Maqbool, A., Haleem, A., \& Khan Mohd, I. (2020). Analyzing critical success factors for a successful transition towards circular economy through DANP approach. Management of Environmental Quality: An International Journal, 31(3), 505-529. https://www.emerald.com/insight/content/doi/10.1108/MEQ-09-2019-0191/full/html

Kolk, A. (2016). The social responsibility of international business: From ethics and the environment to CSR and sustainable development. Journal of World Business, 51(1), 23-34. https://doi.org/10.1016/j.jwb.2015.08.010

Liao, L., Luo, L., \& Tang, Q. (2015). Gender diversity, board independence, environmental committee and greenhouse gas disclosure. The British Accounting Review, 47(4), 409-424. https://doi.org/https://doi.org/10.1016/j.bar.2014.01.002

Liu, J., Yuan, C., Hafeez, M., \& Li, X. (2020). ISO 14001 certification in developing countries: motivations from trade and environment. Journal of Environmental Planning and Management, 63(7), 1241-1265. https://doi.org/10.1080/09640568.2019.1649642

Liu, W., Tang, L., \& Hu, G. (2020). Funding information in Web of Science: an updated overview. Scientometrics, 122(3), 1509-1524. https://doi.org/10.1007/s11192-020-03362-3

Margolis, J. D., Elfenbein, H. A., \& Walsh, J. P. (2007). Does it pay to be good? A meta-analysis and redirection of research on the relationship between corporate social and financial performance. Ann Arbor, 1001, 48109-41234. https://doi.org/10.2139/ssrn.1866371

Matten, D., \& Moon, J. (2008). "Implicit" and "Explicit" CSR: A Conceptual Framework for a Comparative Understanding of Corporate Social Responsibility. Academy of management review, 33(2), 404-424. https://doi.org/10.5465/amr.2008.31193458

Mazzoni, F. (2020). Circular economy and eco-innovation in Italian industrial clusters. Best practices from Prato textile cluster. Insights into Regional Development, 2(3), 661-676. https://doi.org/10.9770/IRD.2020.2.3(4)

McGuire, J. B., Sundgren, A., \& Schneeweis, T. (1988). Corporate Social Responsibility and Firm Financial Performance. Academy of management Journal, 31(4), 854-872. https://doi.org/10.5465/256342

McWilliams, A., \& Siegel, D. (2000). Corporate social responsibility and financial performance: correlation or misspecification? Strategic management journal, 21(5), 603-609. https://doi.org/10.1002/(SICI)1097-0266(200005)21:5<603::AID-SMJ101>3.0.CO;2-3

McWilliams, A., Siegel, D. S., \& Wright, P. M. (2006). Corporate Social Responsibility: Strategic Implications. Journal of management studies, 43(1), 1-18. https://doi.org/10.1111/j.1467-6486.2006.00580.x 


\section{ENTREPRENEURSHIP AND SUSTAINABILITY ISSUES}

ISSN 2345-0282 (online) http://jssidoi.org/jesi/

2020 Volume 8 Number 2 (December)

http://doi.org/10.9770/jesi.2020.8.2(83)

Make your research more visible, join the Twitter account of ENTREPRENEURSHIP AND SUSTAINABILITY ISSUES: @Entrepr69728810

Orlitzky, M., Schmidt, F. L., \& Rynes, S. L. (2003). Corporate Social and Financial Performance: A Meta-Analysis. Organization studies, 24(3), 403-441. https://doi.org/10.1177/0170840603024003910

Orlitzky, M., Siegel, D. S., \& Waldman, D. A. (2011). Strategic corporate social responsibility and environmental sustainability. Business \& Society, 50(1), 6-27. https://doi.org/10.1177/0007650310394323

Özmen Uysal, Ö. (2010). Business Ethics Research with an Accounting Focus: A Bibliometric Analysis from 1988 to 2007. Journal of Business Ethics, 93(1), 137-160. https://doi.org/10.1007/s10551-009-0187-9

Peters, W. (1993). Use of methods and evaluation systems of the impact mitigation principle in German EIA. Journal of Environmental Impact Assessment, 2(2), 49-53. https://www.koreascience.or.kr/article/JAKO199328062536624.pdf

Porter, M. E. The Competitive Advantage: Creating and Sustaining Superior Performance. NY: Free Press, 1985. (Republished with a new introduction, 1998.)

Porter, M. E., \& Kramer, M. R. (2006). The link between competitive advantage and corporate social responsibility. Harvard business review, 84(12), 78-92. https://hbr.org/2006/12/strategy-and-society-the-link-between-competitive-advantage-and-corporate-socialresponsibility

Reinhardt, F. L. (1998). Environmental Product Differentiation: Implications for Corporate Strategy. California management review, 40(4), 43-73. https://doi.org/10.2307/41165964

Reinhardt, F. L., \& Stavins, R. N. (2010). Corporate social responsibility, business strategy, and the environment. Oxford Review of Economic Policy, 26(2), 164-181. https://doi.org/10.1093/oxrep/grq008

Rudyanto, A. \& Pirzada, K. 2020. The role of sustainability reporting in shareholder perception of tax avoidance. Social Responsibility Journal, Vol. ahead-of-print No. ahead-of-print. https://doi.org/10.1108/SRJ-01-2020-0022

Sarkis, J., Gonzalez-Torre, P., \& Adenso-Diaz, B. (2010). Stakeholder pressure and the adoption of environmental practices: The mediating effect of training. Journal of operations Management, 28(2), 163-176. https://doi.org/https://doi.org/10.1016/i.jom.2009.10.001

Seuring, S., \& Müller, M. (2008). From a literature review to a conceptual framework for sustainable supply chain management. Journal of Cleaner Production, 16(15), 1699-1710. https://doi.org/https://doi.org/10.1016/j.jclepro.2008.04.020

Sharma, S., \& Henriques, I. (2005). Stakeholder influences on sustainability practices in the Canadian forest products industry. Strategic management journal, 26(2), 159-180. https://doi.org/10.1002/smj.439

Shaukat, A., Qiu, Y., \& Trojanowski, G. (2016). Board Attributes, Corporate Social Responsibility Strategy, and Corporate Environmental and Social Performance. Journal of Business Ethics, 135(3), 569-585. https://doi.org/10.1007/s10551-014-2460-9

Small, H. (1973). Co-citation in the scientific literature: A new measure of the relationship between two documents. Journal of the American Society for information Science, 24(4), 265-269. https://doi.org/10.1002/asi.4630240406

Stefan, A., \& Paul, L. (2008). Does It Pay to Be Green? A Systematic Overview. Academy of Management Perspectives, 22(4), 45-62. https://doi.org/10.5465/amp.2008.35590353

Surroca, J., Tribó, J. A., \& Waddock, S. (2010). Corporate responsibility and financial performance: the role of intangible resources. Strategic management journal, 31(5), 463-490. https://doi.org/10.1002/smj.820

Tvaronavičienè, M., \& Ślusarczyk, B. (2019). Energy transformation towards sustainability. Energy transformation towards sustainability (pp. 1-333) https://doi.org/10.1016/C2018-0-02510-4 Retrieved from www.scopus.com

Vachon, S., \& Klassen, R. D. (2008). Environmental management and manufacturing performance: The role of collaboration in the supply chain. International journal of production economics, 111(2), 299-315. https://doi.org/https://doi.org/10.1016/j.ijpe.2006.11.030

Vanraan, A. F. J. (1990). Fractal dimension of co-citations. Nature, 347(6294), 626-626. https://doi.org/10.1038/347626a0 


\section{ENTREPRENEURSHIP AND SUSTAINABILITY ISSUES}

ISSN 2345-0282 (online) http://jssidoi.org/jesi/

2020 Volume 8 Number 2 (December)

http://doi.org/10.9770/jesi.2020.8.2(83)

Make your research more visible, join the Twitter account of ENTREPRENEURSHIP AND SUSTAINABILITY ISSUES: @Entrepr69728810

Wang, L., Xue, X., Zhao, Z., \& Wang, Z. (2018). The Impacts of Transportation Infrastructure on Sustainable Development: Emerging Trends and Challenges. International journal of environmental research and public health, 15(6), 1172. https://doi.org/10.3390/ijerph15061172

Ye, N., Kueh, T.-B., Hou, L., Liu, Y., \& Yu, H. (2020). A bibliometric analysis of corporate social responsibility in sustainable development. Journal of Cleaner Production, 272, 122679. https://doi.org/https://doi.org/10.1016/j.jclepro.2020.122679

Yeganeh Kia, H. (2020). A typology of sources, manifestations, and implications of environmental degradation. Management of Environmental Quality: An International Journal, 31(3), 765-783. https://www.emerald.com/insight/content/doi/10.1108/MEQ-02-2019$\underline{0036 / \text { full/html }}$

Zeng, S. X., Ma, H. Y., Lin, H., Zeng, R. C., \& Tam, V. W. Y. (2015). Social responsibility of major infrastructure projects in China. International Journal of Project Management, 33(3), 537-548. https://doi.org/https://doi.org/10.1016/j.ijproman.2014.07.007

Zhao, X., Zuo, J., Wu, G., \& Huang, C. (2019). A bibliometric review of green building research 2000-2016. Architectural Science Review, 62(1), 74-88. https://doi.org/10.1080/00038628.2018.1485548

Zhu, J., \& Liu, W. (2020). A tale of two databases: the use of Web of Science and Scopus in academic papers. Scientometrics, 123(1), 321335. https://doi.org/10.1007/s11192-020-03387-8

\section{Acknowledgements}

The research was supported by the National Natural Science Foundation of China (No. 11761012) and the National Social Science Fund of China (No. 16AGL017). The researcher would like to thank to Mr. Melvin for the proofreading of paper.

Zixuan ZENG is the PhD candidate in Faculty of Logistics and Supply Chain, Naresuan University, Thailand. A lecturer in Faculty of Management Science and Engineering, Guangxi University of Finance and Economics, China. Research interests: strategy; innovation; firm internationalization; sustainability.

ORCID ID: $\underline{\text { https://orcid.org/0000-0002-1439-5520 }}$

Thammanoon HENGSADEKUL, is the lecturer in Faculty of Logistics and Supply Chain, Naresuan University, Thailand. A PhD in Asian Institute of Technology. Research field: project management and construction management, real estate management, family business management; transportation.

ORCID ID: https://orcid.org/0000-0001-8049-5821

Copyright (C) 2020 by author(s) and VsI Entrepreneurship and Sustainability Center This work is licensed under the Creative Commons Attribution International License (CC BY). http://creativecommons.org/licenses/by/4.0/

CC) (i) Open Access 